\title{
Improving the Quality of Public Policy by Involving Stakeholders and the Community
}

\author{
Didin Muhafidin \\ Universitas Padjadjaran, Bandung, Indonesia \\ Email: didin_muhafidin@yahoo.co.id
}

\begin{abstract}
This article is attempting to investigate cooperation, one of the vital Great Administration components, as one concept which is expounded not as it were as only partaking, but too contains an exertion to control awareness to inundate within the entire political handle really. There ought to be a genuine ruddy line between going to per se and partaking with information. Fair interest may be a frame of pseudo support, which is built up based on mobilization. Cooperation with mindfulness, on the other hand, is more contributing to making essential changes within the political handle. Within the setting of support, this sort of understanding is vital. Other than, this article is considered any frame of open interest in defining arrangements to oversee Indonesia, mainly the local people. They got to be relatively acknowledged, especially after the application of neighborhood independence, whether or not they specifically relate with broader open interface. This moreover plays a feedback of fair interest in Indonesia, which has caused Indonesia to be cleared out behind by created nations due to the latter's mind blowing political mindfulness. Advancement may be well running by depending on the government quality, but the comes about will be much way better when the occasion completely get open bolster and cooperation.
\end{abstract}

Keywords: Public Policy, Policy Formulation, Community Participation.

\section{A. INTRODUCTION}

Today we need to appreciate the one step correctly forward in managing our government, especially the regional governments, both regencies; and cities. That step forward is the explicit formulation of the prerequisites for participation as part of the policy formulation process. This populist vocabulary coexists with transparency and accountability and is a measure and verification of the extent to which success and the process of governance management are carried out.

It becomes clear that public participation in the formulation of government management policies in the regions, which directly or those that do not correlate with broad public interests should be appreciated proportionally. One side is a necessity that local governments cannot avoid because of the entanglement of access to development funds, which is a global trend. The other hand can be in the form of political accommodation from the insistence of critical public awareness around the implementation of democracy, which encourages the local government's political management style. 


\section{Meaning Pseudo Participation}

Participation has become a common vocabulary and is very well known by the people, especially political actors. Participation suddenly became something that should be encouraged, especially after the issuance of the Regional Autonomy Law No. 22/1999 to Law No. 32/2004. As with public policy, participation has various meanings, according to the background, understanding, and interests of each translator. This diversity of meanings ultimately influences the mechanism of participation in making decisions on public matters. Two groups have had different views about participation. First, the state administrators group, both executive and legislative. Second, groups from regions affected by participation, namely the community.

For government and regional communities, the primary value of this decentralization policy is the realization of political equality, namely the opening of public participation in various political activities at the national level. The second value is local accountability, namely local governments' ability to pay attention to community rights at the local level. And the third value is local responsiveness, where local governments are considered to know more about the various problems faced by their communities. So through the implementation of decentralization, it is expected that community empowerment can accelerate through the role of local government.

Participation is not merely involved or participating, but controlling a kind of awareness to engage in the political process properly. It must be distinguished between participation as mere participation and participation as a form of consciousness. Attendance, which is participation, is a form of artificial participation. This participation is built by motives mobilization. Conversely, participation based on a type of awareness seeks more to make fundamental changes in the political process. This understanding is essential in the context of participation. Not politics here is a form of relations that occur in everyday life.

The British Council in 2001 mentioned that there were 21 types of public participation techniques. These techniques are 1. Plan for Action; 2. Action, Creating, Experience (ACE); 3. Choosing Method; 4. Citizens Jury; 5. Community Assessment; 6. Community Indicator; 7. A Vision That Will Sacrifice the Future; 8. Future Search; 9. Guided Visualization; 10. Imagine; 11. Local Carrying Capacity Model; 12. Outdoor; 13. Environmental Map; 14. Participatory Assessment; 15. Participatory strategy planning; 16. Participatory Theater; 17. Real Planning; 18. Round Table Workshop; 19. Social Audit; 20. Studio Talk; 21. Team Integrity.

Twenty-one kinds of techniques are the result of participation in research The British Council in several countries. The participation technique formulated by The British Council is applied in all decision-makers, both political, economic, social, cultural, and public infrastructure development. All models of participation are actively carried out by the government, picking up the aspirations of citizens by holding various kinds of meetings involving all stakeholders. That is quite advanced from the method of 
participation carried out in several countries, really accommodating all the people's opinions, and then being a guarantee for taking steps to build the country.

How about in Indonesia? We must admit that not many types of participation substantially involve the public. It must be recognized that the mechanism that has been carried out so far is still far behind what has been done by other countries outside Indonesia, especially Europe.

In making public policy decisions, Indonesian officials prefer to conduct comparative studies to other regions rather than the difficulty of conducting public consultations, aka picking up the ball amid the community, so that in general, it can be seen that the process of participation exists in Indonesian regions goes like that.

The pressure is needed on public officials with a mechanism of reward and punishment in the form of regulations for public policy-making mechanisms.

\section{Elements of Good Governance Participation}

The concept of Good Governance behind this campaign was aggressively campaigned as a solution to get out of the crisis. Behind the campaign comes the necessity to change perspective. If in the past, the administration of government has always been seen from the perspective of the government, now we are invited to look at the problem from the public criticism. What is considered necessary by the public does not seem relevant from the government's point of view? vice versa. Finally, there is a gap between those governors and those who govern (the people/people).

The urgency of the institutionalization of Good Governance to participate in the success of the government reform plan correlates with the insistence of here and there for government renewal. As an umbrella of the schedule, Good Governance is translated into some jargon, such as (1) participation, (2) transparency, (3) law enforcement, (4) responsiveness, (5) accountability, and so on.

Good governance occurs when there is a high level of correspondence between what the community wants and what the government does. Through the development of participation, people take advantage of the broadest opportunities to help determine the course of government. On the other hand, public policy-making is demanded to be responsive to the demands of society. Decisions taken in the context of developing governance are required to be accountable to the public. Law enforcement is an absolute necessity for interaction between the state and community to be orderly and optimal.

Opened space for public participation in policy formulation, whatever is the driving factor for its presence, must be positioned as an opportunity for all development stakeholders. To be actively involved in the maturation of the process of democracy and fairer governance and public welfare in the broadest sense, by first considering the following matters: 
First, Public Participation is a plan that must not be manipulated and eliminated. Second, our public (read: mass) has not yet been built into well-organized units of interest and even tends to disintegrate and continually experience the process of destroying its collective power. Meanwhile, the effectiveness and efficiency of the participatory process presuppose sectoral representation that legitimately represents the interests of organized public sector aspirations based on profession, economic activity, case community, to shared interests. Third, the masses of our people are unprepared to articulate their expectations and needs proportionally, so that continuous learning of aspirational skills needs to be expressed, expressing opinions, and making demands on their collective needs. Fourth, Patron-Client Presence and withdrawal ideological claims of political forces and public interest. Fifth, the existence of a legal umbrella as a guarantee of the continuity of public participation in policy formulation.

What is an excellent form of participation? It is indeed ironic if provocation is the right way to grow the participation of the masses because the people are accustomed to "charging" the government. Or there is a concern that the government must instead work with the work of provocateurs to develop a participatory government. Not to mention the big question who the heck is most entitled to determine the size of the government is good or not good? If our participation is believed to be a pillar of government administration, as well as a series of other related fundamental questions, who should participate in the government's plan? Is it the central plan that must follow the list of the local government or vice versa? A dilemma arises on the one hand, 'participation' is treated as a solution; on the other hand, 'participation' actually becomes a problem!

How is a transparent government developed? Transparent government is a government that opens wide access to the public to determine what is done by the government. People call it the government in the sunshine! Running a government is like working in the bright sunlight, so everyone can criticize it if you don't like it. This means that the government must be given 'enlightenment' (illuminated)!

On the one hand, the government is expected to reveal (self-exposing) himself presented to the public; on the other hand, the public should be ensured access to the heart of government agenda: decision-making. In the plurality of people in this country (both in terms of interests, value preferences, and community traditions), the idea of starting to develop government transparency can only lead to chaos. Government openness can invite people to cheat the government. Once again, the offer of a solution to the problem brings the problem.

In connection with the above, we must look for government standards (good/bad). If we are serious about upholding democracy as a pillar of the state's administration, then a good government is a democratic government. The good and bad of a government is measured by whether or not the principles of democracy are fulfilled. That is, the implementation of good governance (good governance) in this 
perspective is synonymous with democratic governance. Critical, good governance is the commitment, mechanism, and democratic institutional arrangements.

\section{B. METHOD}

The method used in this study is a descriptive qualitative approach to the method of literature study using secondary data in the form of literature relating to public participation in the formulation of public policy (Lambert \& Lambert, 2012; Neergaard et al., 2009).

\section{RESULT AND DISCUSSION}

\section{What's Wrong with Public Policy?}

It is undeniable, we often hear, witness, and even feel the events of rising city transportation costs, increasing prices of daily necessities, urban planning, low ability to buy people due to low wages and incomes, urban planning that does not benefit the community, increases fuel oil, traffic regulations, curbing street vendors (street vendors), the selection of commercial sex workers (CSWs), rising electricity costs, motor vehicle tax increases, garbage collection, parking fees, low RMW (regional minimum wage), etc.

The events that take place around us, as in the example above do not occur naturally, or as something that happens because of a normal process of development. In various events that occur in society, the state policy (public policy) is what gives color to the occurrence of these events. The state policy in question is a policy that is developed or formulated by the agency the agency as well as government officials. In this connection, non-governmental or private actors can undoubtedly influence the development or formulation of policies.

Because the definition of public policy tends to be different, implementation in the field also experiences a lot of misinterpretation. This misinterpretation can usually be seen in various kinds of rulemaking, in the form of laws, government regulations, judicial decisions, including local regulations, as a tangible form of public policy.

At least various motivations for the formation of local regulations are obtained the justification. The motives for the creation include. First, the structure of local regulations is often associated with the effort to get funding from "above". It is said that the general allocation fund (GAF), special allocation fund (SAF), and the balance fund will only flow if the regional governments have established regulations on the village government. Second, local governments only rely on regulations to overcome various problems. Not infrequently, the rules that are formed by the problem do not originate from the absence of regulations, but because the implementation is not working. Third, what is most frequently stated in many studies and research reports is that the establishment of these local regulations is intended to tackle the regional budget deficit by increasing taxes and levies. 
In addition to the three factors above, many other factors influence the formation of local regulations, including the uniformity of rules, political courts, and the continuation of discrimination. This is the fundamental problem of regional autonomy because of public involvement in public policy-making, including the process of forming local regulations.

Public policy is a real form of the spirit of the state, and public policy is a concrete form of the process of contact between the state and its people. Transparent and participatory public policies will contribute significantly to the creation of a good governance system; a rigid and unresponsive public policy paradigm will produce inflexible and unresponsive citizens, and vice versa, a flexible and responsive public policy paradigm produce citizens which is flexible and responsive too.

\section{Community Needs for Participation}

The experience in the New Order period has been very clear, that a development process, or a process of government administration, both central and regional, that does not involve the community, as the subject of development, will only lead to the operation of decay because what the government develops is the same does not reflect what is desired and what is needed by the community.

The development journey in Indonesia or other countries shows that for successful development, community participation is needed. Development can indeed also work by relying on the power that is in the government. Still, the results will not be the same when compared to development that has the support and participation of the community (Kartasasmita, 1995).

Rendra said in the community contained "Day of Life"; the day life involves intellect, organizational talent, creativity. The power of death includes tyrannize, imperialism, anarchy, oligarchy, mafia, prostitution, corruption, criminality in all its forms, the power of death that accompanies humans from birth and can always disrupt the elements of life force.

Analogous with Rendra's opinion, in the context of public policy also contained "life force" and "dead power". Life force in the form of community participation in the process of determining policies that will be applied in the governance of the life of the Indonesian people. As for the power of death, which is more pathological and tries to eliminate all or part of the aspirations that come from the people.

Participation is the core of democracy; participation is formed through the process of reaching collective agreement or consensus. Consensus as a result of the deliberations then becomes a joint guideline, which initially disagreed after the proceedings became agreed to join in and support the agreement.

Increasing community participation does not merely involve the community in the planning stage or mere project evaluation. In participation implied the meaning and integrity of the whole project. Participation is an attitude of openness to the perceptions 
and feelings of others; participation means in-depth attention to the differences or changes that a project will produce in relation to community life.

Community participation is often feared as a divisive influence. This excessive concern over the inherent dangers of participation is in line with the definition of development as capital-intensive and growth-oriented, and consistent with the description of administration as a top-down hierarchical structure.

From a political point of view, according to Huntington, participation is divided into two kinds, namely autonomic participation and mobilization participation. Free participation arises from awareness, self-will, and voluntary, while mobilization participation is driven even sometimes forced (Kuswartojo, 1993). Adherents who consider democracy as a right give high value to free participation, but in reality, many participation begins with mobilization.

Participation is rather easy to say and is often offered as an application of the concept of development from below, but this participation is related to various complicated aspects. Participation concerns ideology, the political system, and also the socio-economic and cultural conditions of society. Participation in development must also be carried out as part of evolution itself; if not, what happens is only apparent participation without any continuation and satisfying results.

Community participation or participation is considered to be the key to the success of development down to the bottom level. For example, Uma Lele reviewed African rural development projects and found that participation was a positive and essential component. Participation in planning and implementing programs can develop the self-reliance needed by members of rural communities for accelerated development.

To increase community participation, Frances F. Korten (1989) pointed out several obstacles, namely constraints in implementing agencies, in his community, and broader community institutions (the more full institutions of the society). Restrictions in the implementing agencies include the party making the decision; attitudes, values and skills; and evaluation system. Constraints in the community itself include the incompatibility of local organizations, lack of organizational skills, lack of communication facilities, as well as differences in economic interests that occur between groups of people; and corruption. Other obstacles encountered in increasing community participation are related to political and bureaucratic elements.

\section{CONCLUSION}

In people-centered or participatory governance, the policy is placed as a sociopolitical process where citizens negotiate the allocation of goods and the public budget. The policy is not just limited to technical problems that can be solved technocratically by a group of people who are trusted to formulate it (usually politicians, bureaucrats, or academics). The policy is a space for technicians and community members to interact 
and combine the knowledge. Therefore policies must involve broad parties, and to be implemented must ensure that the interests of various parties (stakeholders) have been confronted or negotiated.

In this perspective, participation is not seen as a means but rather an end in itself. This is intended as an effort to realize Good Governance in the implementation of policies in Indonesia. Therefore, the formulation of this policy framework is carried out through various public consultations to develop public participation in formulating public policies. Broad community participation can benefit local governments to be more transparent and accountable, whereas top-down rules from the elite can kill the spirit of civil society.

\section{REFERENCES}

1. Brugha, R., \& Zwi, A. (1998). Improving the quality of private sector delivery of public health services: challenges and strategies. Health policy and planning, 13(2), 107-120.

2. Dee, T. S. (1998). Competition and the quality of public schools. Economics of Education review, 17(4), 419-427.

3. Dill, D. D., \& Soo, M. (2005). Academic quality, league tables, and public policy: A cross-national analysis of university ranking systems. Higher education, 49(4), 495533.

4. du Plessis, A. (2008). Public Participation, Good Environmental Governance and Fulfilment of Environmental Rights. Potchefstroom Electronic Law Journal/Potchefstroomse Elektroniese Regsblad, 11(2), 1-34.

5. Dye, T. R., \& Dye, T. R. (1992). Understanding Public Policy. Englewood Cliffs, NJ: Prentice Hall.

6. Gaventa, J., Valderrama, C., Edin, E., \& Kusumawijaya, M. (2001). Mewujudkan Partisipasi: 21 Teknik Partisipasi Masyarakat Untuk Abad 21. British Council.

7. Hagerty, M. R., Cummins, R., Ferriss, A. L., Land, K., Michalos, A. C., Peterson, M., ... \& Vogel, J. (2001). Quality of life indexes for national policy: Review and agenda for research. Bulletin of Sociological Methodology/Bulletin de Méthodologie Sociologique, 71(1), 58-78.

8. Kartasasmita, G. (1995). Pemberdayaan Masyarakat: Sebuah Tinjauan Administrasi. Universitas Brawijaya.

9. Korten, F. F., \& Siy, R. Y. (1989). Transforming a bureaucracy: The experience of the Philippine national irrigation administration.

10. Kuswartojo, T. (1993). Peranan LPSM dalam Meningkatkan Partisipasi Masyarakat dalam Pembangunan Desa. Jakarta. 
11. Lambert, V. A., \& Lambert, C. E. (2012). Qualitative descriptive research: An acceptable design. Pacific Rim International Journal of Nursing Research, 16(4), 255256.

12. Lubis, S. (2007). Partisipasi Masyarakat dalam Kebijakan Publik. Jurnal Demokrasi, 6(1).

13. Meier, K. J., \& O'Toole Jr, L. J. (2002). Public management and organizational performance: The effect of managerial quality. Journal of Policy Analysis and Management: The Journal of the Association for Public Policy Analysis and Management, 21(4), 629-643.

14. Neergaard, M. A., Olesen, F., Andersen, R. S., \& Sondergaard, J. (2009). Qualitative description-the poor cousin of health research?.BMC medical research methodology, 9(1), 52.

15. Rendra, W. S. (2001). Penyair dan Kritik Sosial, Yogyakarta: KEPEL Press.

16. Riege, A., \& Lindsay, N. (2006). Knowledge management in the public sector: stakeholder partnerships in the public policy development. Journal of knowledge management.

17. Sihombing, E. N. (2018). Pembentukan Peraturan Daerah Partisipatif. OSF Preprints. July 31. doi:10.31219/osf.io/kdqmn.

18. Turnbull, S. (1997). Stakeholder governance: A cybernetic and property rights analysis. Corporate Governance: An International Review, 5(1), 11-23.

19. Wahab, S. A. (2008). Pengantar Analisis Kebijakan Publik. Malang: UPT Penerbitan Universitas Muhammadiyah.

20. Wu, F., Jacobs, D., Mitchell, C., Miller, D., \& Karol, M. H. (2007). Improving Indoor Environmental Quality for Public Health: Impediments and Policy Recommendations. Environmental Health Perspectives, 115(6), 953-957. 